\title{
The Academic Stress of Final-Year Students in Covid-19 Pandemic Era
}

\author{
Syahrilı, Sitti Riadil Janna², Fatimah3 \\ DOI: $10.35445 /$ alishlah.v13i1.407
}

\section{Article Info}

Keywords:

Academic Stress

Covid-19

Final-Year Students

Kata kunci:

Stres Akademik

Covid-19

Mahasiswa Akhir

\section{Abstract}

This study aims to reveal the academic stress of final students in the current Covid-19 pandemic era. The research design used a quantitative descriptive survey of 113 students from various universities in Indonesia, including undergraduate (bachelor), master, and doctoral education levels. The research instrument used an academic stress scale developed by the researcher, which consisted of twelve question items. The distribution of the tool was carried out using google forms. The results showed that several factors caused student academic stress. There are cost factors (difficulty paying tuition fees / UKT and demands to return the scholarship), study conditions (difficulty consulting with supervisors/promoters and unable to find references in the library), and personal problems (conflicts with friends or with a partner and less comfortable boarding/house conditions). Student academic stress is the highest experienced by doctoral students compared to undergraduate and master's level students. Online counselling is recommended to help students experiencing academic stress to complete their studies on time.

\begin{abstract}
Abstrak
Penelitian ini bertujuan mengungkap stres akademik mahasiswa tingkat akhir di era pandemic Covid-19 saat ini. Desain penelitian menggunakan deskriptif kuantitaif dengan jumlah responden sebanyak 113 mahasiswa dari berbagai perguruan tinggi di Indonsia yang terdiri dari jenjang pendidikan S1 (sarjana), S2 (magister) dan $\left(\mathrm{S}_{3}\right)$ doktor. Instrumen penelitian menggunakan skala stress akademik yang dikembangkan sendiri oleh peneliti yang terdiri dua belas item pertanyaan. Penyebaran instrumen dilakukan dengan menggunakan google formulir. Hasil penelitian menujukkan bahwa stres akademik mahasiswa disebabkan oleh faktor biaya (kesulitan membayar uang kuliah/ UKT dan tuntutan mengembalikan beasiswa), kondisi studi (kesulitan konsultasi dengan pembimbing/ promotor dan tidak dapat mencari referensi di perpustakaan), dan problem pribadi (konflik dengan teman atau dengan pasangan dan kondisi kost/ rumah yang kurang nyaman). Stress akademik mahasiswa paling tinggi dialami mahasiswa jenjang doktor dibanding jenjang sarjana dan magister. Penggunaan konseling online direkomendasikan agar dapat membantu
\end{abstract}

\footnotetext{
${ }^{1}$ Insitut Agama Islam Negeri (IAIN) Bone, Watampone, Indonesia

Email: syahril@iain-bone.ac.id

${ }^{2}$ Universitas Islam Negeri (UIN) Alauddin Makassar, Gowa, Indonesia

Email: riadiljanna.uinalauddin@gmail.com

3 Insitut Agama Islam Negeri (IAIN) Bone, Watampone, Indonesia

Email: fatimah.stainwatampone@gmail.com

Vol.13 (1) June, 2021

Received: February 2, 2021; Received in revised form: February 22, 2021; Accepted: February 26, 2021; Available online: March 30, 2021

This is an open access article under a Creative Commons Attribution-NonCommercial-ShareAlike 4.o International License
} 
mahasiswa yang mengalami stress akademik sehingga mahasiswa dapat menyelesaikan studi tepat waktu

\section{INTRODUCTION}

The world is currently encountering the Covid-19 pandemic. It emerged at the end of December 2019 in Wuhan, China (Chahrour et al., 2020). The World Health Organization (WHO) declared the coronavirus pandemic and declared it a public health emergency of international concern (Meng et al., 2020; Singh \& Adhikari, 2020). As of February 26, Covid-19 has spread rapidly to 34 countries, with a total of 80,239 infected cases and 2,700 deaths (WHO, 2020).

The Covid-19 pandemic impacted the global economy negatively (Cavallo \& Forman, 2020; Nicola et al., 2020; Haleem et al., 2020). It also affects the education field (Rundle et al., 2020; Sintema, 2020), social (Bostan et al., 2020), environment (Chakraborty \& Prasenjit, 2020), sports (Parnell et al., 2020), (Usher et al., 2020; A. Kumar \& Nayar, 2020). As a result, governments in various countries have made multiple efforts to stop the spread of Covid-19. The World Health Organization (WHO) encourages people to practice social and physical distancing (WHO, 2020). China (Lau et al., 2020), India (Pulla, 2020; Lee, 2020), Italy (Chintalapudi et al., 2020), France (Roques et al., 2020), Malaysia (Salim et al., 2020; Altahir et al., 2020), and Vietnam (Salim et al., 2020) all participated in the lockdown (Le et al., 2020). Meanwhile, the Indonesian government uses large-scale social restrictions (known as PSBB, large-scale social limits) instead of a lockdown (Nurlaila et al., 2020). The consequence of the lockdown or PSBB is the limited community activities to carry religious activities in worship houses (mosques, churches, temples, temples, etc.), in public places/facilities, school holidays, and workplaces (PP No. 21 Tahun 2020). PP All activities are carried from home or known as Work from Home (WFH) (Mungkasa, 2020).

For students, the dismissal of lecture activities on campus and all learning activities at home due to the Covid-19 pandemic impact their mental health (Cao et al., 2020; Lee, 2020). Online learning tasks cause students to experience stress (Livana, Mubin Mohammad Fatkhul \& Basthomi, 2020). Tang et al. (2020) found post-traumatic stress disorder (PTSD) and student depression in China.

Stress is a psychological disorder that most people in this age group, including students, experience (Gomathi et al., 2012). On the other hand, stress can affect cognitive function by disrupting behavior, thoughts, and moods if it occurs frequently and excessively (Ahmad et al., 2019). Mood disorders can affect their learning and thinking abilities by causing mental, physical, and emotional problems (Stallman, 2010). Academic, social, family, and health issues are sources of stress for students (Cheryl Maykel, 2018). Academic stress is stress caused by educational activities (Akram \& Kahn, 2012). Academic stress is a type of mental stress caused by academic failure (Krishan, 2013).

Academic stress is stress related to learning activities, in the form of tension originating from educational factors, resulting in distortions in mind and affecting students' physical, emotional, and behavior (Nurmaliyah, 2014). Academic stress has become a common problem experienced by students in various countries, cultures, and ethnic groups (Wong et al., 2007). Students experience academic stress due to poor study habits (Nakalema \& Ssenyonga, 2013), excessive assignments and pressure to attain high achievement ( $\mathrm{Liu} \& \mathrm{Lu}, 2011$ ), competition between students in the class (Misra \& Castillo, 2004), financial pressure (Assaf et al., 2017), fear of failure and indigent relationship with lecturers (Phillips et al., 2020).

Expectations from parents and teachers make students experience academic stress (Calaguas, 2012). Parents hope that their children will get high academic achievement in each exam, making students depressed (Neuenschwander et al., 2007). Likewise, the teacher's hope that each student completes the assignment correctly and according to the set schedule makes them stressed. 
Students in the current era of the Covid-19 pandemic have to change how they learn from face-to-face to online. Online lectures necessitate technological know-how and various tasks in a variety of subjects (Wahyu \& Nurul, 2020). Students in their final year are also stressed as they work on their thesis and dissertation. They are unable to research due to social distancing policies and the fact that they can only communicate with their supervisors via email and social media platforms such as WhatsApp. Because of the limited time for discussion, students found it difficult (Elvira, 2020).

As a result, more researchers research the causes of academic stress in final-year students during the Covid-19 pandemic era. It also looks for what problem-solving to students who are experiencing academic stress. They require assistance in dealing with academic pressure, which has a broad impact on student life (S. Kumar \& Jadaun, 2018) and has become a severe university issue (Phillips et al., 2020). Academic stress impacts students' physical and mental health (MacGeorge et al., 2005). Academic stress relates to anxiety and depressive symptoms in adolescents (Jayanthi et al., 2015), and it also impacts student wellbeing (Cheryl, 2018). High academic stress also influences the students' health and academic performance (Yumba, 2010).

Research on student academic stress in the Covid-19 era has been studied by researchers such as Andiarna et al. (2020), who examined the effect of online learning on student academic stress. Then, Sari et al. (2020) analyzed the relationship between student academic stress and limited internet access while studying during the Covid-19 pandemic. Both studies have not examined in detail the academic stress of late-year students in the Covid-19 pandemic era. Therefore, it is necessary to research the academic stress of final year students in the Covid-19 pandemic era.

This research is essential to conduct. The results of this research will determine the intervention model or assistance provided by parties related to students who experience academic stress in the Covid-19 pandemic era so that these students can complete their studies on time without being hindered by pandemic conditions.

\section{METHOD}

This research design is descriptive quantitative. The Respondents' number was 113 students consisting of 80 undergraduate students, 20 students at the master's level, and 30 doctoral students. The respondents come from various universities in Indonesia, currently working on their final assignments (undergraduate thesis, magister thesis, and dissertation). The instrument used was an academic stress scale developed from various sources as many as twelve question items consisting of three indicators: personal problems, study conditions, and tuition fees. The scale has a Cronbach alpha of 0.75 . The distribution of the instruments is done via a google form. Data collection was carried out for five months (July-November 2020). The data obtained were analyzed using descriptive techniques with univariate analysis and then made in a frequency distribution.

\section{FINDING AND DISCUSSION}

Based on the results of data analysis from the academic stress scale, the following will describe the research findings made in the form of frequency distribution based on gender, causes of academic stress, education level, and student academic stress levels:

\section{Gender}

Table 1: student academic stress based on gender

\begin{tabular}{|c|c|c|c|}
\hline \multirow{2}{*}{ Variable } & \multirow[b]{2}{*}{ Category } & \multicolumn{2}{|c|}{ Amount } \\
\hline & & $\mathrm{N}$ & $\%$ \\
\hline \multirow[t]{4}{*}{ Male } & High & 2 & $4,76 \%$ \\
\hline & Medium & 24 & $57,14 \%$ \\
\hline & Low & 16 & $38,09 \%$ \\
\hline & Total & 42 & $100 \%$ \\
\hline \multirow[t]{3}{*}{ Female } & High & 4 & $5,71 \%$ \\
\hline & Medium & 38 & $54,28 \%$ \\
\hline & Low & 28 & $40 \%$ \\
\hline
\end{tabular}

Table 1 shows that $4.76 \%$ of men have a high academic stress level, $57,14 \%$ are in the medium category, and $38,09 \%$ are in a low category. Meanwhile, $5.71 \%$ of women were in the high category, 
$54.28 \%$ were in the medium category, and $40 \%$ were in the low category. These results indicate that, in general, academic stress is experienced by men. This study's results contradict previous research conducted by Sutjiato et al. (2015), describing more women who experience stress than men. The reason is the dominant use of feelings in dealing with a problem and tends to be more emotional and sensitive to what is happening in their environment (Sulaeman et al., 2009). Meanwhile, men are more likely to use reason than when facing a problem.

\section{Causes of academic stress}

Tabel 2. Causes of academic stress

\begin{tabular}{llrr}
\hline \multirow{2}{*}{ Variable } & Category & $\mathrm{N}$ & Amount \\
\cline { 3 - 4 } Personal problems & High & 3 & $\%$ \\
& Medium & 41 & $2,65 \%$ \\
& Low & 69 & $36,28 \%$ \\
& Total & $\mathbf{1 1 3}$ & $61,06 \% \%$ \\
\hline \multirow{5}{*}{ Study conditions } & High & 21 & $100 \%$ \\
& Medium & 57 & $18,58 \%$ \\
& Low & 35 & $50,44 \%$ \\
& Total & $\mathbf{1 1 3}$ & $30,97 \%$ \\
\hline Tuition fees & High & 19 & $100 \%$ \\
& Medium & 42 & $16,81 \%$ \\
& Low & 52 & $37,16 \%$ \\
& Total & 113 & $46,01 \%$ \\
\hline
\end{tabular}

Table 2 shows that in personal problems, as many as three students, or $2.65 \%$ are in the high category, 41 students or $36.28 \%$ are in a low category, and 69 students or $61.06 \%$ are in a low category. In this study, 21 students or $18.58 \%$ were in the high category. 57 students, or $50.44 \%$, were in the medium category, and 35 students or $30.97 \%$, were in a low category. While tuition fees, 19 students or $16.81 \%$ were in the high category, 42 or 37.16 were in the medium category, and 52 or $46.01 \%$ were in the low category.

The research results on the causes of academic stress indicate that the conditions of study and the tuition fees are the causes of students experiencing academic stress. This result is supported by Hamzah B \& Hamzah (2020) research, which shows that the study conditions cause a person to experience academic stress during the current Covid-19 pandemic. Learning that is usually carried out in the classroom becomes online (Livana et al., 2020). Therefore, students must adapt to being online learning with multiple assignments. Completion of these tasks takes a little time (Hamzah B \& Hamzah, 2020).

The problem of tuition fees is also the cause of a person experiencing stress (Robotham, 2008). The research results by Nakalema \& Ssenyonga (2013) revealed that the cost factor is one of the factors that cause students to experience academic stress. For students who are stressed due to being constrained by tuition fees, it will be difficult for students to buy books that are not available in the library. Besides, the cost of photocopying and printing the revised final project is a stressor due to cost difficulties (Tarwiyah et al., 2020).

In the Covid-19 pandemic, many parents of students have been dismissed from companies. They have lost their income and jobs due to this outbreak (Rohmah \& Syari, 2020). Accordingly, students will find it difficult to pay tuition fees and meet their needs. Therefore, tuition fee relief assistance and Internet quota need to be given to students in this pandemic era (Ikhwan Nur Rois, 2020; Ermawati et al., 2020).

\section{Education level}


Tabel 3 : student academic stress based on education level

\begin{tabular}{|c|c|c|c|}
\hline \multirow{2}{*}{ Variable } & \multirow{2}{*}{ Category } & \multicolumn{2}{|c|}{ Amout } \\
\hline & & $\mathrm{N}$ & $\%$ \\
\hline \multirow{4}{*}{ S1 } & High & 1 & $1,40 \%$ \\
\hline & Medium & 39 & $54,92 \%$ \\
\hline & Low & 31 & $43,66 \%$ \\
\hline & Total & 71 & $100 \%$ \\
\hline \multirow[t]{4}{*}{ S2 } & High & 4 & $14,28 \%$ \\
\hline & Medium & 17 & $60,71 \%$ \\
\hline & Low & 7 & $25 \%$ \\
\hline & Total & 28 & $100 \%$ \\
\hline \multirow[t]{4}{*}{$\mathrm{S}_{3}$} & High & 11 & $44 \%$ \\
\hline & Medium & 7 & $28 \%$ \\
\hline & Low & 7 & $28 \%$ \\
\hline & Total & 25 & $100 \%$ \\
\hline
\end{tabular}

The results of table 3 show that academic stress is generally experienced by doctoral students (S3). As many as eleven students, or 44\%, experienced academic stress in the high category. Seven students, or $28 \%$, experienced academic stress in the medium category, and seven students or $28 \%$, also experienced academic stress in the low category.

Students' high academic stress in doctoral programs is caused by anxiety about finances because they already have a social responsibility to their wives, children, and elderly people (Smith et al., 2006). Not to mention the demand to return the scholarship funds totalling twice the government's amount through the applicable repayment mechanism if they cannot complete their studies following the stipulated time (Direktorat Jenderal Pendidikan Tinggi, 2011). It is experienced by students who received scholarships from the Indonesian Ministry of Religion.

Doctoral education is the most difficult of all academic levels (Gardner \& Holley, 2011). Doctoral education takes a long time, takes a lot of effort and money so that many students experience psychological pressure so that they are unable to complete their studies (Pyhältö et al., 2012). Therefore, students need to be helped to manage their stress well because it can interfere with their wellbeing, impacting their dissertation completion productivity (Russell-Pinson \& Harris, 2019).

\section{Academic Stress Level}

Table 4. Student Academic Stress Level

\begin{tabular}{cccc}
\hline \multirow{2}{*}{ Variable } & \multirow{2}{*}{ Category } & $\mathbf{N}$ & Amount \\
\cline { 3 - 4 } & & 6 & \% \\
\hline Academic Stress & High & 63 & $5,30 \%$ \\
& Medium & 44 & $55,75 \%$ \\
& Low & $\mathbf{1 1 3}$ & $38,93 \%$ \\
\hline
\end{tabular}

Table 4 showed that as many as six students, or 5.30\% experienced stress levels in the high category. Sixty-three students or 55, 75\% were in the medium category. As many as 44 students or $38.93 \%$ of students were in a low category. Even though only six students are in the high category, 63 students are in the medium category that needs attention because students who experience academic stress will hurt physical and mental health and do academic tasks well (Akgun \& Ciarrochi, 2003).

Doctoral education is the most difficult of all academic levels (Gardner \& Holley, 2011). Doctoral education takes a long time, takes a lot of effort and money so that many students experience psychological pressure so that they are unable to complete their studies (Pyhältö et al., 2012). Therefore, students need to be helped to manage their stress well because it can interfere with their wellbeing, impacting their dissertation completion productivity (Russell-Pinson \& Harris, 2019). 
Therefore, to cope with stress at the academy, students must develop defence mechanisms and adapt to stressors that trigger stress from academic life (Smeltzer et al., 2008). Besides, through acceptance, planning, and positive reframing, students can make the necessary efforts to overcome academic stress (Sreeramareddy et al., 2007).

Higher-education institutions need to help overcome student academic stress by creating a conducive educational environment so that the learning process can be better, focusing on meeting student needs(Joseph E. Angolla \& Ongori, 2009). Another way that can be done is by providing counselling, relaxation training, and academic resilience (Wang et al., 2020).

\section{CONCLUSION}

The Covid-19 pandemic currently hitting the world has an impact on academic stress for finalyear students. Students experience academic stress due to study conditions and tuition fees as a result of Covid-19. The effect is they worry that they will be hampered in completing the study. Academic stress is felt the most by doctoral students. The government needs to help students reduce their study costs and maximize higher education stakeholders, such as academic advisers, to assist students who experience academic stress in online counselling. Online counselling helps a person through a technology application to allow counselling to occur without coming in person directly using a website/ site, telephone/ mobile phone, email, and video conferencing. Online counseling is also called e-counselling

\section{REFERENCES}

Ahmad, R., Naqvi, A. A., Al-Bukhaytan, H. M., Al-Nasser, A. H., \& Baqer Al-Ebrahim, A. H. (2019). Evaluation of aromatherapy with lavender oil on academic stress: A randomized placebo controlled clinical trial. Contemporary Clinical Trials Communications, 14(August 2018), 100346. https://doi.org/10.1016/j.conctc.2019.100346

Akgun, S., \& Ciarrochi, J. (2003). Learned Resourcefulness Moderates the Relationship between Academic Stress and Academic Performance. Educational Psychology, 23(3), 287-294. https://doi.org/10.1080/0144341032000060129

Akram, M., \& Kahn, I. M. (2012). Assessment of Academic Stress and Problem Solving among Senior Secondary School Students. Social Science International, 28(2), 265-274.

Altahir, A. A., Mathur, N., Thiruchelvam, L., Mustafa Abro, G. E., Radzi, S. S. M., Dass, S. C., Gill, B. S., Sebastian, P., Zulkifli, S. A. M., \& Asirvadam, V. S. (2020). Modeling the impact of lockdown on COVID-19 spread in Malaysia. BioRxiv, July, 1-20. https://doi.org/10.1101/2020.07.17.208371

Andiarna, Funsu \& Kusumawati, E. (2020). Effects of Online Learning on Student Academic Stress During the Covid-19 Pandemic. Jurnal Psikologi, 16(2), 139-150.

Assaf, A. M., Al-Abbassi, R., \& Al-Binni, M. (2017). Academic stress-induced changes in Th1- and Th2-cytokine response. Saudi Pharmaceutical Journal, 25(8), 1237-1247. https://doi.org/10.1016/j.jsps.2017.09.009

Bostan, S., Erdem, R., Öztürk, Y. E., Kılıç, T., \& Yılmaz, A. (2020). The effect of COVID-19 pandemic on the Turkish society. Electronic Journal of General Medicine, 17(6). https://doi.org/10.29333/ejgm/7944

Calaguas, G. M. (2012). Parents/teachers and self-expectations as sources of academic stress. International Journal of Research Studies in Psychology, 2(1), 43-52. https://doi.org/10.5861/ijrsp.2012.136

Cavallo, J. J., \& Forman, H. P. (2020). The economic impact of the COVID-19 pandemic on radiology practices. Radiology, 296(3), E141-E144. https://doi.org/10.1148/radiol.2020201495

Chahrour, M., Assi, S., Bejjani, M., Nasrallah, A. A., Salhab, H., Fares, M. Y., \& Khachfe, H. H. 
(2020). A Bibliometric Analysis of COVID-19 Research Activity: A Call for Increased Output. Cureus, 2(December 2019), 1-8. https://doi.org/10.7759/cureus.7357

Cheryl Maykel, J. deLeyer-T. and M. A. B. (2018). Academic Stress: What Is the Problem and What Can Educators and Parents Do to Help? Positive Schooling and Child Development: International Perspectives, 1-435. https://doi.org/10.1007/978-981-13-0077-6

Chintalapudi, N., Battineni, G., \& Amenta, F. (2020). COVID-19 virus outbreak forecasting of registered and recovered cases after sixty day lockdown in Italy: A data driven model approach. Journal of Microbiology, Immunology and Infection, 53(3), 396-403. https://doi.org/10.1016/j.jmii.2020.04.004

Direktorat Jenderal Pendidikan Tinggi. (2011). Pedoman Beasiswa Pendidikan Pascasarjana (BPPS).

Elvira. (2020). Curhat Mahasiswa Tingkat Akhir saat Pandemi Covid-19. https://ayobandung.com/read/2020/04/14/85997/curhat-mahasiswa-tingkat-akhir-saatpandemi-covid-19

Ermawati, E., Husaini, A., \& Pakkawaru, I. (2020). Pengaruh Penggunaan Media Sosial Terhadap Keputusan Pembelian Kuota Internet Pada Mahasiswa Fakultas Ekonomi dan Bisnis Islam IAIN Palu. Jurnal Ilmu Ekonomi Dan Bisnis Islam, 2(1), 36-58. https://doi.org/10.24239/jiebi.v2i1.22.36-58

Gardner, S. K., \& Holley, K. A. (2011). "Those invisible barriers are real": The Progression of FirstGeneration Students Through Doctoral Education. Equity and Excellence in Education, 44(1), 77-92. https://doi.org/10.1080/10665684.2011.529791

Gomathi, K. G., Ahmed, S., \& Sreedharan, J. (2012). Psychological Health of First-Year Health Professional Students in a Medical University in the United Arab Emirates. SQU Med J, 12(May), 206-213.

Haleem, A., Javaid, M., \& Vaishya, R. (2020). Effects of COVID-19 pandemic in daily life. Current Medicine Research and Practice. https://doi.org/10.1016/j.cmrp.2020.03.011

Hamzah B \& Hamzah, R. (2020). FAKTOR-FAKTOR YANG BERHUBUNGAN DENGAN TINGKAT STRES AKADEMIK PADA MAHASISWA STIKES GRAHA MEDIKA. Indonesian Journal for Health Sciences, 4(2), 15-16.

Ikhwan Nur Rois. (2020). Implementasi Keringanan Uang Kuliah Tunggal bagi Mahasiswa di Era New Normal. Jambura Journal of Educational Management, 1(September), 103-121. https://doi.org/10.37411/jjem.v1i2.158

Indranil, Chakraborty \& Prasenjit, M. (2020). COVID-19 outbreak: Migration, effects on society, global environment and prevention. Science of the Total Environment, January. https://doi.org/https://doi.org/10.1016/j.scitotenv.2020.138882

Jayanthi, P., Thirunavukarasu, M., \& Rajkumar, R. (2015). Academic stress and depression among adolescents: A cross-sectional study. Indian Pediatrics, 52(3), 217-219. https://doi.org/10.1007/s13312-015-0609-y

Joseph E. Angolla \& Ongori, H. (2009). An Assesment of Academic stress among undergraduate studen: The case of University Botswana. Educ. Res. Rev.

Krishan, L. (2013). Academic stress among adolescent in relation to intelligence and demographic factors. American International Journal of Research in Humanities, Arts and Social Sciences, 5(1), 123-129.

Kumar, A., \& Nayar, K. R. (2020). COVID 19 and its mental health consequences. Journal of Mental Health, o(o), 1-2. https://doi.org/10.1080/09638237.2020.1757052

Kumar, S., \& Jadaun, U. (2018). Effect of Parental Expectations and Academic Stress on Academic Achievement in Higher Studies with Special Reference To District Aligarh. Multidisciplinary Higher Education, Research, Dynamics \& Concepts, 153-161.

Lau, H., Khosrawipour, V., Kocbach, P., Mikolajczyk, A., Schubert, J., Bania, J., \& Khosrawipour, T. (2020). The positive impact of lockdown in Wuhan on containing the COVID-19 outbreak in China. Journal of Travel Medicine, 27(3). https://doi.org/10.1093/jtm/taaao37 
Le, H. T., Nguyen, D. N., Beydoun, A. S., Le, X. T. T., Nguyen, T. T., Pham, Q. T., Ta, N. T. K., Nguyen, Q. T., Nguyen, A. N., Hoang, M. T., Vu, L. G., Tran, B. X., Latkin, C. A., Ho, C. S. H., \& Ho, R. C. M. (2020). Demand for health information on COVID-19 among Vietnamese. International Journal of Environmental Research and Public Health, 17(12), 1-12. https://doi.org/10.3390/ijerph17124377

Lee, J. (2020). Mental health effects of school closures during COVID-19. The Lancet Child and Adolescent Health, 4(6), 421. https://doi.org/10.1016/S2352-4642(20)30109-7

Liu, Y., \& Lu, Z. (2011). The Chinese high school student's stress in the school and academic achievement. Educational Psychology, 31(1), 27-35. https://doi.org/10.1080/01443410.2010.513959

Livana, Mubin Mohammad Fatkhul \& Basthomi, Y. (2020). “Tugas Pembelajaran” Penyebab Stres Mahasiswa Selama Pandemi Covid-19. Jurnsl Ilmu Keperawatan Jiwa, 3(2), 203-208.

MacGeorge, E. L., Samter, W., \& Gillihan, S. J. (2005). Academic stress, supportive communication, and health. Communication Education, 54(4), 365-372. https://doi.org/10.1080/03634520500442236

Meng, L., Hua, F., \& Bian, Z. (2020). Coronavirus Disease 2019 (COVID-19): Emerging and Future Challenges for Dental and Oral Medicine. Journal of Dental Research, 99(5), 481-487. https://doi.org/10.1177/0022034520914246

Misra, R., \& Castillo, L. G. (2004). Academic stress among college students: Comparison of American and international students. International Journal of Stress Management, 11(2), 132-148. https://doi.org/10.1037/1072-5245.11.2.132

Mungkasa, O. (2020). Bekerja dari Rumah (Working From Home/WFH): Menuju Tatanan Baru Era Pandemi COVID 19. Jurnal Perencanaan Pembangunan: The Indonesian Journal of Development Planning , 4(2), 126-150. https://doi.org/10.36574/jpp.v4i2.119

Nakalema, G., \& Ssenyonga, J. (2013). Gladys Nakalema Mbarara University of Science and Technology, Uganda Joseph Ssenyonga Mbarara University of Science and Technology, Uganda. AJOTE, 3(3).

Neuenschwander, M. P., Vida, M., Garrett, J. L., \& Eccles, J. S. (2007). Parents' expectations and students' achievement in two western nations. International Journal of Behavioral Development, 31(6), 594-602. https://doi.org/10.1177/0165025407080589

Nicola, M., Alsafi, Z., Sohrabi, C., Kerwan, A., \& Al-jabir, A. (2020). Since January 2020 Elsevier has created a COVID-19 resource centre with free information in English and Mandarin on the novel coronavirus COVID-19. The COVID-19 resource centre is hosted on Elsevier Connect, the company's public news and information . January.

Nurlaila, I., Hidayat, A. A., \& Pardamean, B. (2020). Lockdown Strategy Worth Lives: The SEIRD Modelling in COVID-19 Outbreak in Indonesia. Researchgate.Net. https://www.researchgate.net/profile/Bens_Pardamean/publication/342657964_Lockdown _Strategy_Worth_Lives_The_SEIRD_Modelling_in_COVID-

19_Outbreak_in_Indonesia/links/5efefa9e458515505087a236/Lockdown-Strategy-WorthLives-The-SEIRD-Modelling-in-COVID-19-Outb

Nurmaliyah, F. (2014). Menurunkan stres akademik siswa dengan menggunakan teknik selfinstruction. Pendidikan Humaniora, 2(3), 273-282.

http://journal.um.ac.id/index.php/jph/article/view/4469/951

Parnell, D., Widdop, P., Bond, A., \& Wilson, R. (2020). COVID-19, networks and sport. Managing Sport and Leisure, o(o), 1-7. https://doi.org/10.1080/23750472.2020.1750100

Phillips, S. C., Halder, D. P., \& Hasib, W. (2020). Academic Stress among Tertiary Level Students: A Categorical Analysis of Academic Stress Scale in the Context of Bangladesh. Asian Journal of Advanced Research and Reports, 8(4), 1-16.

https://doi.org/10.9734/ajarr/2020/v8i430203 
PP No. 21 Tahun 2020. Tentang Pembatasan Sosial Berskala Besar Dalam Rangka Percepatan Penanganan Corona Wrus Disease 2019 (COVID-I9).

Pulla, P. (2020). Covid-19: India imposes lockdown for 21 days and cases rise. BMJ (Clinical Research Ed.), 368(March), m1251. https://doi.org/10.1136/bmj.m1251

Pyhältö, K., Toom, A., Stubb, J., \& Lonka, K. (2012). Challenges of Becoming a Scholar: A Study of Doctoral Students' Problems and Well-Being. ISRN Education, 2012, 1-12. https://doi.org/10.5402/2012/934941

Robotham, D. (2008). Stress among higher education students: Towards a research agenda. Higher Education, 56(6), 735-746. https://doi.org/10.1007/s10734-008-9137-1

Rohmah, S. N., \& Syari, F. (2020). Adakah peluang bisnis di tengah kelesuan perekonomian akibat pandemi Corona virus Covid-19 ? 'ADALAH ; Buletin Hukum \& Keadilan, 4(1), 63-74.

Roques, L., Klein, E. K., Papaïx, J., Sar, A., \& Soubeyrand, S. (2020). Impact of Lockdown on the Epidemic Dynamics of COVID-19 in France. Frontiers in Medicine, 7. https://doi.org/10.3389/fmed.2020.00274

Rundle, A. G., Park, Y., Herbstman, J. B., Kinsey, E. W., \& Wang, Y. C. (2020). COVID-19-Related School Closings and Risk of Weight Gain Among Children. Obesity, 28(6), 1008-1009. https://doi.org/10.1002/oby.22813

Russell-Pinson, L., \& Harris, M. L. (2019). Anguish and anxiety, stress and strain: Attending to writers' stress in the dissertation process. Journal of Second Language Writing, 43(November), 63-71. https://doi.org/10.1016/j.jslw.2017.11.005

Salim, N., Chan, W. H., Mansor, S., Bazin, N. E. N., Amaran, S., Faudzi, A. A. M., Zainal, A., Huspi, S. H., Hooi, E. K. J., \& Shithil, S. M. (2020). COVID-19 epidemic in Malaysia: Impact of lockdown on infection dynamics. MedRxiv, May. https://doi.org/10.1101/2020.04.08.20057463

Sari, N.P, , Setiawan. M. A., Rijiani, I., \& M. F. (2020). Analisis hubungan stres akademik mahasiswa terhadap akses internet terbatas saat belajar selama pandemi covid 19 (studi pada mahasiswa universitas lambung mangkurat dan universitas islam negeri antasari). Universitas lambung mangkurat, November.

Singh, R., \& Adhikari, R. (2020). Age-structured impact of social distancing on the COVID-19 epidemic in India. ArXiv, 1-9.

Sintema, E. J. (2020). Effect of COVID-19 on the performance of grade 12 students: Implications for STEM education. Eurasia Journal of Mathematics, Science and Technology Education, 16(7), 1-6. https://doi.org/10.29333/EJMSTE/7893

Smeltzer SC, Bare BG, Hinkle, JL, Cheever, K. B. and S. (2008). Textbook of Medical-Surgical Nursing. In Wolters Kluwer Health/Lippincott Williams \& Wilkins (12th ed., Vol. 65, Issue 1). Wolters Kluwer Health/Lippincott Williams \& Wilkins;

Sreeramareddy, C. T., Shankar, P. R., Binu, V. S., Mukhopadhyay, C., Ray, B., \& Menezes, R. G. (2007). Psychological morbidity, sources of stress and coping strategies among undergraduate medical students of Nepal. BMC Medical Education, 7, 1-8. https://doi.org/10.1186/14726920-7-26

Stallman, H. M. (2010). Psychological distress in university students: A comparison with general population data. Australian Psychologist, 45(4), 249-257.

https://doi.org/10.1080/00050067.2010.482109

Tang, W., Hu, T., Hu, B., Jin, C., Wang, G., Xie, C., \& Chen, S. (2020). Since January 2020 Elsevier has created a COVID-19 resource centre with free information in English and Mandarin on the novel coronavirus COVID-19. The COVID-19 resource centre is hosted on Elsevier Connect, the company's public news and information . January.

Tarwiyah, A., Mayasari, S., \& Pratama, M. J. (2020). Identifikasi Stressor Akademik Pada Mahasiswa Tahun Ketiga Identification of Academic Stressors in The Third Year. 1.

Usher, K., Durkin, J., \& Bhullar, N. (2020). The COVID-19 pandemic and mental health impacts. International Journal of Mental Health Nursing, 29(3), 315-318. 
https://doi.org/10.1111/inm.12726

Wahyu Rahardjo, Nurul Qomariyah, I. M. \& I. A. (2020). Jurnal Psikologi Sosial : Panic Buying pada Pandemi COVID - 19 : Telaah Literatur dari Perspektif Psikologi. Psikologi Sosial, 18(59), 12. https://doi.org/10.7454/jps.2020.xx

Wang, J. L., Rost, D. H., Qiao, R. J., \& Monk, R. (2020). Academic stress and smartphone dependence among Chinese adolescents: A moderated mediation model. Children and Youth Services Review, 118(April), 105029. https://doi.org/10.1016/j.childyouth.2020.105029

WHO. (2020). Coronavirus Disease (COVID-19). October.

Wong, P. T. P., Wong, L. C. J., \& Scott, C. (2007). Beyond Stress and Coping: The Positive Psychology of Transformation. Handbook of Multicultural Perspectives on Stress and Coping, 1-26. https://doi.org/10.1007/o-387-26238-5_1

Yumba, W. (2010). Academic Stress: A Case of the Undergraduate students Wycliffe Yumba. http://urn.kb.se/resolve?urn=urn:nbn:se:liu:diva-81902 